\title{
SUMMER RECORDS OF HUDSONIAN GODWITS NEAR SASKATOON, SASKATCHEWAN
}

\author{
by J. B. Gollop, Saskatoon
}

This note reports the occurrence of large numbers of Hudsonian Godwits (Limosa haemastica) outside the usual route and tıming of their southward migration.

In the summers of 1970 and 1971 members of the Saskatoon Natural History Society noted Hudsonian Godwits on Porter Lake $\left(52^{\circ} 12^{\prime} \times 106^{\circ}\right.$ $\left.17^{\prime}\right), 11$ miles east-northeast of Saskatoon. This "lake" is an alkali flat about two miles long and averaging less than half a mile in width. It does rot always have water through August but did in these two years. The lake is: more than $99 \%$ devoid of emergent (and probably submergent) vegetation.

In 1970 , seven Hudsonian Godwits were noted on June 27. Other counts by the writer were: eight on July 5 , eight on August 10,81 on August 12 , over 45 on August 19, 59 on August 23, and two on September 5 . In 1971, the first record was for July 10-336 Hudsonians. There were 487 birds (plus about 60 unidentified godwits) on July 14 . On July 15, 616 Hudsonians (plus 77 unidentified) were counted with J. A. Wedgwood. By July 21 there had been another increase, 847 (plus 212 unidentified) being counted with W. C. Harris. There was not a Hudsonian Godwit on Porter Lake or on two similar sloughs within seven miles to the south of it on July 28. However, two Hudsonian Godwits were seen on a slough 30 miles southwest of Saskatoon on July 31.

In both years the Hudsonians were mixed with Marbled Godwits (Limosa fedoa), for which the high count in 1970 was 260 birds on August 12 and 19, and in 1971, 359 birds on July 14. On July 28, 1971, there were five Marbled Godwits on the lake. At least ten other species of shorebirds had also noticeably declined in numbers from the previous week. The number of ducks (dabbling and diving species) on the area during this period dropped from approximately 4000 to approximately 400.

While the godwits occurred in mixed flocks in 1971 , one species usually outnumbered the other in a flock by at least two to one. Marbled Godwits tended to be around the edge of flocks dominated by Hudsonians. On all three cays when the birds were counted (between 6:15 a.m. and 8:00 a.m.), 80 percent or more of the concentration was within 200 yards of the east shore, feeding continuously in shallow water of an estimated depth of from one to two inches.

Hudsonian Godwits are known to breed in two widely separated areas of the Arctic: in the northwest corner of the Mackenzie District and along the Manitoba and Ontario coasts of Hudson Bay (Godfrey, 1966). Godfrey describes the southward migration of both populations as being "remarkably concentrated, passing down the west coast of Hudson and James bays in a lane only a few miles wide." After concentrating there, most of the birds apparently make a 3,000-mile non-stop flight over the Maritime Provinces, probably landing in northern South America, en route to southern Argentina and Chile (Hagar, 1966). Godfrey does not report the species even as accidental in the southern Prairie Provinces on fall migration - July through October for this species. Salt and Wilk (1958) state that, while it is a regular migrant in spring with up to 21 birds being seen at one time, "the fall migration through Alberta is less regular." A review of the Northern and Southern Great Plains regions (roughly the Prairie Provinces to the interior of Texas) in Audubon Field Notes and American Birds for the period June 15 - November 30 from 1961 through 1970 produced seven records: five godwits on three September-October dates at Beaverhill Lake, Alberta (Hatch, 1968, 1969), one in 
North Dakota on July 15 and 25, 1963 (Nero, 1963), and one in Kansas on September 26, 1965 (Williams, 1966). Other "fall" records for the Great Plains include July 21 at Big Stick Irake, Saskatchewan, and July 10 in South Dakota (no numbers, Bent, 1927), five August-October dates for Kansas and Oklahoma, the largest number of birds apparently being four (Sutton, 1967), and from one to 16 birds near Regina, Saskatchewan, during the last week of October, 1950 iBelcher, 1961). Miss M. Belcher has kindly supplied an unpublished record: a single Hudsonian with approximately 20 Marbled Godwits near Regina on July 9, 1968 seen by A. and B. Binnie.

The appearance of anything more than a straggler away from the breeding grounds in July is apparently exceptionally early. Hagar (1966) states, on the basis of data from various sources covering a period of several years up to and including 1965 , that "from the 17th (of July) on, adult Hudsonian Godwits gather on the tidal flats of Hudson Bay and begin to move southeastward. Those individuals which have been guarding chicks are thin, while others, whether sub-adults or unsuccessful nesters, are already putting on fat . . By 23-26 July the vanguard of adults is well down the west coast of James Bay ... Within a day of two of 5 August, the first juveniles appear . . For a week or 10 days in mid-August, virtually the whole species, old and young, is concentrated in a coastal strip only a few miles in width but stretching a thousand miles in length, from Eskimo Point ... north of Churchill to the foot of James Bay ... The last two weeks of August see the main departure of adults from the southern end of James Bay ... (young-of-the-year) leave... between 15 September and 10 October."

The Saskatoon dates do, however, fit in with one of Hagar's (1966) observations. In discussing "minor aspects" of departure, he states: "A number of small mixed flocks of godwits, Short-billed Dowitchers, and
Stilt Sandpipers - from 15 to 55 in a flock - appeared suddenly on the 29th of [June, 1962] . . . and dropped from sight again by 3 July." July reports, other than those given above for birds south of the breeding grounds, include: late July arrival on islands in the Gulf of St. Lawrence (L. C. Sanford in Bent, 1927), one bird on July 13, 1952 in Mexico (Binford, 1970), and a flock of 1,000 near Buenos Aires, Argentina, on July 2, 1880 (Gibson, in Wetmore, 1927).

While there is no current estimate of the total populatin of Hudsonian Godwits, the number on Porter Lake, probably 1,000 birds on July 15 , is among the largest noted in the literature in the last 30 years. Although the species occurred in "bands of thousands" on the wintering grounds a hundred years ago, Wetmore (1927) could find only about 50 in the same area in 1921. Hope and Shortt (1944) reported that "at least 1,000 birds passed our camp" on James Bay, July 23, 1942, and 200 more on July 24. The bird has long been considerd rare but Fisher, Simon and Vincent (1970) state that it was out of danger by 1958. Hagar (1966) wrote that for James Bay "The peak (departure of adults) is usually a day or two either way from 23 August, and the number of birds passing a given point on the ccast, between mid-afternoon and dark of a flight-day, sometimes exceeds three or four thousands." It is conceivable that the 1971 Saskatoon flock included as much as 10 percent of the population of the species.

Neither age nor sex was determined for the Porter Lake birds. Their colour varied from typical breeding plumage to winter pattern. Breeding data (Hagar, 1966; Jehl and Smith, 1970) exclude the possibility of their being young-of-the-year and make it improbable that they were adults that had successfully reared young in the years that they were seen. Considering what is generally accepted to be their migration route, it seems more likely that the Saskatoon birds originated from western rather than eastern Arctic breeding areas. There is apparently no 
information on whether or not all birds of this species normally breed when a year old. Nor are there weather data on hand at this time that might suggest that breeding was unsuccessful in some area in 1971.

It is also interesting that both species of godwits remained through August and into September in 1970. The most noticeable weather factor during the week in 1971 that the birds left was 2.8 inches of rain with strong north winds on July 24.

This movement into the Prairies may be something new in the life cycle of the species. There are no summerfall Saskatoon records prior to 1970 . I $i$ is, nevertheless, possible that a significant portion of the population has stopped over on a lake in the grassland. parkland sections of the Prairie Provinces more often than the records indicate.

The writer wishes to thank C. S. Houston and J. A. Wedgwood for comments on the manuscript.

\section{LITERATURE CITED}

Belcher, M. 1961. Birds of Regina. Sask. Nat. Hist. Soc., Spec. Pub. 3. 76 p.

Bent, A. C. 1927. Life histories of North American shore birds. Part 1. U.S. Nat. Mus. Bull. 142. 420 p.

Binford, L. C. 1970. Audubon's Shearwater, Hudsonian Godwit, and Long-tailed Jaeger in Oaxava, Mexico. Condor, 72-366.

Fisher, J., N. Simon, and J. Vincent. 1969. The red book - wildlife in danger. Collins, London, $368 \mathrm{pp}$.

Godfrey, W. E. 1966. The birds of Canada. Nat. Mus. Canada. Bull. 203. Queen's Printer, Ottawa. 428 p.

Hagar, J. A. 1966. Nesting of the Hudsonian Godwit at Churchill, Manitoba. Living Bird, $5: 5-43$.

Hatch, D. R. M. 1968. Northern Great Plains Region. Audubon Field Notes, 22:54-57.

Hatch, D. R. M. 1969. Northern Great Plains Region. Audubon Field Notes, $23: 70-74$.

Hope, C. E., and T. M. Shortt. 1944. Southward migration of adult shorebirds on the west coast of James Bay, Ontario. Auk, 61 :572576.

Jehl, J. R. Jr.. and B. A. Smith. 1970. Birds of the Churchill Region, Manitoba. Man. Mus. Man and Nature Spec. Pub. 1. Winnipeg, Man. 87 p.

Nero, R. W. 1963. Northern Great Plains Region. Audubon Field Notes, 17:467-468.

Salt, W. R., and A. L. Wilk. 1958. The birds of Alberta. Queen's Printer, Edmonton, Alta. $511 \mathrm{p}$.

Sutton, G. M. 1967. Oklahoma Birds. Univ. Oklahoma Press, Norman. $674 \mathrm{p}$.

Wetmore, A. 1927. Our migrant shorebirds in southern South America. U.S. Dep. Agr. Tech. Bull. 26. 24 p.

Williams, F. 1966. Southern Great Plains Region. Audubon Field Notes, $20: 64-66$.

\section{EUROPEAN WIDGEON SIGHTING AT CUMBERLAND HOUSE, SASKATCHEWAN}

by David T. Little, Cumberland House

Three students and I observed a pair of European Widgeon at Cumberland House on May 7, 1971. The male was identified as a bird of this species; the female was presumed to be the same. The birds were first spotted swimming in a ditch on Cumberland Island. We first watched them from the car about 100 yards away, using two pairs of field glasses, $7 \times 35$ and $7 \times 50$. We then slowly approached to within 50 yards, at which distance we could see very easily the male's reddish head with the pale yellow forehead. The forehead marking was not so pronounced as that shown in the picture on page 76 of Earl Godfrey's Birds of Canada. The male's body was light greyish in colour; the female was more of a brownish colour on the breast than the male.

At this point a horse and rider scared the pair and they flew away. Though I watched the ditch for several weeks afterwards and also visited the surrounding sloughs, I did not see the ducks again.

Because I have hunted and watched ducks since I was a young boy, I can readily recognize most ducks of Saskatchewan. Also, we had Godfrey's Birds of Canada in the car with us and while watching the birds we carefully checked every duck. They were definitely European Widgeons.

\section{SIGHT RECORD OF A SNOWY EGRET AT CYPRESS LAKE, SASKATCHEWAN}

by Wayne C. Weber, Vancouver, B.C.

On June 19, 1970, at about 6:00 p.m., I had the good fortune to observe a Snowy Egret (Leucophoyx thula) at the Cypress Lake dam, south of Maple Creek, Saskatchewan. As I drove onto the dam, I flushed the egret, which was then about 75 feet from me, as well as several Great Blue Herons which accompanied it. The egret 